\title{
Mathematical Comic Media for Problem Solving Skills
}

\author{
Sri Adi Widodo ${ }^{1,2, a}$, Turmudi ${ }^{1, b}$, Jarnawi Afgani Dahlan ${ }^{1, \mathrm{c}}$, Istiqomah²,d ${ }^{2,}$ Hanandyo Saputro ${ }^{2, \mathrm{e}}$ \\ sriadi@ustjogja.ac.id ${ }^{\mathrm{a}}$, turmudi@upi.edu ${ }^{\mathrm{b}}$, jarnawi@upi.edu ${ }^{\mathrm{c}}$, istiqomah@ustjogja.ac.id ${ }^{\mathrm{d}}$, \\ hanandyo@ustjogja.ac.id
}

${ }^{1}$ Universitas Pendidikan Indonesia, Bandung, Indonesia

${ }^{2}$ Universitas Sarjanawiyata Tamansiswa, Yogyakarta, Indonesia

\begin{abstract}
Students need to learn the problem-solving skill with which students can become a problem solver on a daily basis in their environment. Year-seven students have been in their formal phase of physical age; however, many of the students may mentally be still in the particular stage. Thus, the latter students are in the period of transition between solid phase to abstract. Mathematical comics media is one of the media that may able to bridge the transition from particular stage to abstract because the learning of mathematics becomes meaningful when it is adjusted with, the characteristic of the cognitive development of the students. One of the supporting aspects of knowledge is the use of the instructional media being applied. Comics media can allegedly improve problem-solving skills of year-seven students.
\end{abstract}

Keywords: Mathematical Comics Media, Problem Solving, Transition Phase

\section{Introduction}

Problems are a situation faced by someone, who needs a solution, and the steps to answer the question are not immediately recognized [1]. When one has a problem, a person's cognition experience a disequilibrium (imbalance) condition which is usually characterized by questioning what exactly the problem is, how to solve the problem, or why it may be so. Disequilibrium will lead to the processes of assimilation and accommodation [2]. When one does not have a particular pattern to follow in narrowing the gap of a current situation with the achievement goal, problems may occur. If one has a specific design to close the difference, then the one may have solved the problems. So if a person can integrate the new information directly into a scheme that has already been established or someone can apply the old project into a further scheme adjusting to the existing data to achieve an equilibrium, then the person has done the problem-solving process.

In the mathematics education world, mathematical problems are usually in the form of questions or math problems that must be answered by learners. Issues can be presented in the way of non-routine matters in the way of stories, depictions of phenomena or events, illustrations of images or puzzles, and mathematical concepts [3]. Mathematical problems are the problems which are linked to calculations and efficiency in daily life. The mathematical problem becomes a problem when the question is challenging to be solved or answered, and there is no routine procedure to follow in solving the problem $[4,5]$. If students are given a mathematical problem, and they have already recognized the process for resolving it, and then 
they can solve the question accurately, it cannot be categorized as a problem for the students [6].

Insufficient students' ability in solving math problems may cause the students learning achievement less optimal. It can be noticed from the students' inconsistent ways in solving the math problems [7]. The students' inconsistent ways show that the students ' focus is only on the answering stage without doing the solving steps $[4,8,9]$. Thus, it is difficult for the teacher to notice whether the student has understood the math problem and the way in solving it. Also, students' assessment instruments are in the multiple-choice form such as in midterms, semester exams, and school exams. Descriptive questions are used in daily quizzes only, the impact of this condition is the teachers assume that the result is the only goal in solving the problem [10].

The teacher's end-result assumption above does not make consistent with the idea that students should learn the problem-solving skill. There are several reasons why students should acquire the problem-solving talent. First, problem-solving related to the students daily life. The problem-solving ability can be used to provide solutions to the problems so that the students can be analytical problem solvers. Second, in learning, concept, and ideas can be developed with problem-solving skill. Third, there are five mathematics learning standards stated in the principles and rules of the school mathematics: one of them is related to the process of problemsolving, reasoning and evidence, connection, communication, and representation [11]. Four, the objectives of learning in Indonesia are to solve problems comprised the ability to understand issues, design mathematical models, complete the model, and interpret the solutions obtained. Five, the primary student's basic competence in the modern mathematics curriculum in Indonesia is that a student can think and act effectively and creatively in the realm of abstract and concrete by the learned sources in school and other similar sources, and a student can solve problems related to the mathematics material.

Previous research found that by using teaching media, students' achievement and problemsolving ability are better. Math learning turns to be more effective [12]. The recent trend of teaching media is a computer-based technology such as GeoGebra, flash, or powerpoint. The challenge in developing such computer-based media is that not all schools have supporting devices such as LCDs and projectors. Another problem is the media used by the teacher has not accommodated the students ' differences yet, especially differences in cognitive development. This is like Ojose who argued that with attention to student cognitive development, mathematics learning can become more meaningful [13]. Teachers should recognize the students' cognitive development in the learning process.

In this regard, the students' cognitive development have to be considered in creating learning media, particularly for junior high school students. This study, thus, aims to discuss the learning media to develop problem-solving skill.

\section{Method}

This research is a preliminary study, so it does not intend to assess a learning device. This preliminary study consists of two stages: defining and designing which are part of Define, Design developt and disseminated or 4D [14]. At the defining stage, it is undertaken to set and define development requirements such as curriculum analysis, material analysis, and objective formulation. The designing stage set up a learning device prototype or a product design which is, in this study, hypothetic mathematical-learning comic. The creating of the of mathematics 
learning comics is conducted at the designing stage. The comics were developed by the analysis results of the curriculum content and material framework.

\section{Results and Discussion}

Four stages of cognitive development of Piaget are the sensory-motor stage from birth to 2 years of age; preoperational stage from 2 years until seven years; concrete operations stage from 7 years to 12 years, and formal operations stage from 12 years to adulthood $[13,15]$. Each step of child's cognitive development has unique characteristics. As in the concrete operational phase children, begin to understand logically stable. They can simplified classifications, based on shared traits, be able to sequence things accurately, can develop imagination into the past and the future, can think argumentatively and solve the problems. Student gets ideas, as adults do, but cannot believe abstract because their way of thinking is limited to a concrete [13, 15-17]. In the formal operational stage, children are capable of thinking abstract, scientific reasoning, theoretic thinking, debate and test hypotheses that priority the ability to think, able to solve problems logically by involving various related issues [17]. The consequence of such individual difference is that the children should be provided different reading materials too [11]. This is in line with Ojose who stated that learning would be meaningful if adapted to the child's cognitive development [13]. This includes selecting the learning media tailored according to the characteristics of learners and teaching materials that will be given to the students [18].

Teachers have rarely noticed learners' cognitive development which is one of the learners ${ }^{\text {c }}$ characteristics. The teachers should notice the students cognitive development which means that if students used the operational concrete, the abstract concept should not be used in learning. It should be considered that the success of teaching and learning process, among others, is influenced by the suitability between the teaching material and the level of learners ' cognitive development $[11,13]$. Thus, if a student achieves a concrete cognitive, the mathematics teacher is advised not to use formal stage of mathematical learning. Instead, the precise step of mathematical knowledge is adjusted to the specific action.

The age of junior high school students has already in the formal stage[13]. They are no longer in the concrete stage but they mentally still can be found in the step of concrete as the stage of formal thinking has not been achieved. As suggested by Syahbana that junior high school students cannot entirely think in the abstract scene, the presence of concrete objects is still needed in learning mathematics [11]. Teachers should also begin to introduce semi-concrete objects in learning mathematics. This is because physically the year-seven students are in the formal operational stage so that in learning mathematics they can use abstract concept. However, the seventh graders are sometimes mentally still at a concrete operational stage.

It should be noted that in primary school, students may have applied practical mathematical concepts. In junior high school, students are expected to be more advanced which is the formal stage. However, the students in this study have not achieved the formal stage yet which means that the students are in the transition stage from the concrete operational to the official or abstract operational [11].

Learning tools are needed to achieve such objectives. Learning tools are used to carry out processes that enable teacher and student to conduct learning activities [19]. Permendikbud 65 2013 pointed out that the preparation of learning tools which is a part of learning planning is designed in the form of the syllabus, lesson plans, development of learning media and learning 
resources, assessment tools, and learning scenarios. It can be noticed that media is one of the components needed for learning. With a media, the teaching can be implemented effectively[12], and messages delivered by teachers are accepted to stimulate the students ${ }^{6}$ thoughts, feelings, attention so that later it will encourage the students to learn. Messages brought by the learning media can be information prepared to meet the learning needs, and the student's ability so can actively participate in the learning.

Learning media is a supportive communication tool to convey a message to the student and to stimulate to achieve the learning objectives. In selecting the media, the teachers need to consider the learning objectives to be delivered; tailored to the level of development of the students; the media should be tailored to the ability of the teachers and must be adjusted to the situations and the conditions. In addition, media should be interconnected with other components in order to create the expected learning situations, making the abstract concrete, to reduce the occurrence of verbalism, improve stimulus in learning activities, reduce misunderstanding to the teachers' explanations, broaden horizon, enable direct interaction between learners with their environment, produce uniform observation, generate motivation, and stimulate student to learn $[10,11]$.

To be effective in teaching mathematics, the teachers need a good teaching plan which comprises careful consideration. One of the things that should be carefully planned in addition to the use of models, strategies, and approaches in the teaching and learning process is learning tools such as syllabus, lesson plan, teaching media and learning resources, assessment instruments, and teaching scenarios. To utilize the teaching media well and effectively, the teachers need to pay attention to some aspects such as analyzing learner characteristics, stating teaching objectives, selecting and modifying or designing materials, utilizing materials, requiring learners' response, and evaluating. Also, the selection of media should also consider the characteristics of the stuff that will be given to students, the characteristics of learners or individual differences, facilities supporting the teaching, and using the principles of assuring and visuals [11].

One characteristic of individual differences is the difference among learners cognitive development. As stated in the previous section that, by age, year-seven students are already in the formal stage, but mentally they are sometimes still in the particular phase. Students have not in the official period yet because the scenes in the specific period have not been entirely passed [13]. Every single student will give a series of qualitative changes that are stable, always fixed, not leaping or backward, in other words, the particular stage of thinking has not entirely done. It shows that year-seven students are in a transition phase from concrete to abstract or formal.

In learning, the success of teaching and learning process, among others, is influenced by the suitability of the subject matter and the level of students' thinking ability $[13,20]$. When the child reaches a particular cognitive development, the mathematics teacher is advised not to use formal mathematical learning, but mathematics is brought toward the concrete. If students are still at a particular stage of development, teachers should again use real things. Like the occurrence of a primary school teacher who teaches the concept of $3 \times 4$ multiplication. It should not be distinguished from the formal form $4 \times 3$. This is related to the cognitive development of primary school children who are still in the concrete phase, so they can not distinguish formal form from $3 \times 4$ with $4 \times 3$. But if the child is already in the formal phase, the teacher must distinguish the formal form from $3 \times 4$ and $4 \times 3$.

To bridge the cognitive development of junior high school students who are in the transition stage, it is necessary to set learning activities that support the scene. This is because the learning of mathematics will be meaningful if adapted to the cognitive development of the learners [18]. Learning tools such as teaching materials become one of the learning sections that can bridge 
the transition process. Teaching materials that have been used by learners need to be modified and adjusted to be able to serve students' stages. This needs to be done as one factor which influences the success of learning mathematics is the suitability of learning materials learners cognitive development stage [13].

As in children reading activities, children have different reading levels which acquire different book grades. Children who are still in sensory-motor stage does not need to be given a reading book because they still use focus more on hearing sense. In the pre-operational and concrete stage, reading books accompanied by drawings are very helpful to comprehend the texts. In the formal step, children can learn a novel book that is already abstract [17]. Junior high school students who are in the transitional phase can be introduced to semi-concrete objects so that the students' dependence on events or concrete objects can be reduced and help students concrete their thinking stage [21]. Besides that, by using semi-concrete objects, the students ${ }^{6}$ thinking processes can be used to understand and solve problems [11].

Although science and technology are rapidly developed, they are sometimes not used correctly. As figured out by Susanto, Dwijanto, and Sikandar in developing a cell-based learning media namely CELMI or Cellular Explorer Learning Movie Instruction [22]. The background of the development of this media is the increasingly abusive use of the mobile telephone by students. As a result, the printed media is still needed for learners. This is in line with some schools condition which cannot provide information technology media such as the LCD and computer. In this setting, alternative media is needed, for example; number lines are one example of semi-concrete media [23], number cards provide an understanding of the number concept for mentally disabled students, the mathematical comic can be used as an alternative to mathematics learning in junior high school [11]. Comic math is a learning media in the form of instructional materials with a predetermined order layout and intended to convey information or generate the response from the speaker.

The success of students in learning depends mostly on the way material presentation, media use and teaching methods used by teachers [10]. Learning media interconnect with other components so that the learning media is expected to make real an ideal material, increase student interest to gain, and reduce student misconception [11]. Unfortunately, the students tend to be message recipients that the communication in the learning process does not happen. In fact, learning requires students to participate as a communicator or messenger so that there are two-way communication and even many-way communication [24]. In a conversation about knowledge, learning media is needed to improve the effectiveness of learning achievement goals. That is, the learning process will occur if there is a communication between the recipient of the message with the source of the news through the media. Also, the success of teaching and learning process is also influenced by the suitability of the subject matter and the level of students' thinking ability [10], [11].

An excellent teaching plan, teaching strategies that have been prepared very well, as well as teaching materials that have been adapted to the level of students cognitive stage will be in vain if the media used is not appropriate. Because the teaching success is determined by two main components namely teaching methods and teaching media [10]. Both of these components are interrelated and inseparable. The use and selection of any particular teaching method have inevitable consequences on types of instructional media.

The use of teaching media can generate new desires and interests, make motivation, and stimulate learning activities, and will bring psychological influences on students, help students improve understanding, interestingly and reliably present data, facilitate interpretation of data, and compact information [11]. By using the right media, mathematics concepts can be readily accepted by students so that math learning becomes more effective [10]. Junior high school 
students who are at the stage of development of the transition from concrete to formal event required a medium of learning that can bridge the development of its change to the teacher as the sender of the message (in the form of materials or mathematical concepts) needs to think about the right type of media used in the teaching.

The develop mathematical comics reflects the real-life life on a daily basis. This is done to facilitate students to understand mathematical formality. By following this mathematical formulation, students are expected to be able to solve math problems that occur in everyday life. In this way, students are trained to get used to solving problems, so that students can make decisions quickly and accurately, and skillfully in gathering relevant information. They can analyze data and realize the need to re-examine the results it has gained [3]. In other words, the students can provide solutions or answers to problems faced more analytical so that the students can be problem solvers. This is in line with the notion of realism which holds that the material world of something does exist or happen. The world has the essence of reality composed of the physical world and the spiritual world. Knowledge is the accurate picture of what is in the real world. A theory is considered reliable when it is real, and substantively exists, and indeed is true, does not contemporary fiction [25].

By using comic math, the problem-solving steps are told structurally and systematically. Students are expected to be able to apply the problem-solving steps after reading the funny math. Problems such as not writing down what is known, what is asked, not able to list the solving steps, not understand what to do and not able to convey sufficient terms and conditions of necessity will not appear every time the students solved the problem [7, 8].

\section{Conclusion}

The ability to solve problems is an activity to find solutions to mathematical problems derived from a situation between expectations and reality. This activity required an instructional media that implies the steps of problem-solving so the message related concepts and mathematical theories can be sent quickly to the students. Also, the learning media used should be able to bridge the student's cognitive development who are in the transition stage. Media comic math is one of the learning media for seven-year students who are in the transition phase. Mathematical comic media are structured and systematically arranged to familiarize students to solve math problems. Based on these results it is necessary to perform a comic math assessment of mathematical learning to be able to know the level of validation.

\section{References}

[1] S. Posamentier, A. S; Krulik, Problem Solving In Mathematics, Grades 3-6: Powerful Strategies To Deepen Understanding. Canada: Corwin Press, 2009.

[2] J. Hayes et al., "Self and Identity Worldview Accommodation : Selectively Modifying Committed Beliefs Provides Defense Against Worldview Threat Worldview Accommodation : Selectively Modifying Committed Beliefs Provides Defense Against Worldview Threat," vol. 8868, no. April 2016, 2015.

[3] S. A. Widodo, A. S. Purnami, and R. C. I. Prahmana, "Team accelerated instruction, initials, and problem-solves ability in junior high school," Int. J. Emerg. Math. Educ., vol. 1, no. 2, pp. 193-204, 2017. 
[4] S. A. Widodo, "ERROR ANALYSIS OF GUARDIANS STUDENT IN UNDERSTANDING THE PROBLEM OF DIVERGENCE," in Proceeding of International Conference On Research, Implementation And Education Of Mathematics And Sciences 2014, 2014, no. May, pp. 18-20.

[5] S. A. Widodo, "Guardian Student Thinking Process in Resolving Issues Divergence," vol. 11, pp. 431-437, 2017.

[6] S. A. Widodo, R. C. I. Prahmana, A. S. Purnami, and Turmudi, "Teaching materials of algebraic equation,” J. Phys. Conf. Ser., vol. 943, no. 1, pp. 1-6, 2017.

[7] Pardimin and S. A. Widodo, "Increasing Skills of Student in Junior High School to Problem Solving in Geometry with Guided," J. Educ. Learn., vol. 10, no. 4, pp. 390 395, 2016.

[8] S. A. Widodo, "Development of Teaching Materials Algebraic Equation To Improve Problem Solving," Infin. J., vol. 6, no. 1, p. 59, 2017.

[9] S. A. Widodo, "Increasing Skills of Student in Junior High School to Problem Solving in Geometry with Guided," vol. 10, pp. 390-395, 2016.

[10] S. A. Widodo, Darhim, and T. Ikhwanudin, "Improving mathematical problem solving skills through visual media Improving mathematical problem solving skills through visual media," J. Phys. Conf. Ser., vol. 948, no. 1, pp. 1-6, 2018.

[11] S. A. Widodo and Wahyudin, "Selection of Learning Media Mathematics for Junior School Students," Turkish Online J. Educ. Technol., vol. 17, no. 1, pp. 154-160, 2018.

[12] M. Bulut, H. Ü. Akçakın, and G. Kaya, "The Effects of GeoGebra on Third Grade Primary Students 'Academic Achievement in Fractions," vol. 11, no. 2, pp. 347-355, 2016.

[13] B. Ojose, "Applying Piaget's Theory of Cognitive Development to Mathematics Instruction," Math. Educ., vol. 18, no. 1, pp. 26-30, 2008.

[14] S. Thiagarajan, D. S. Semmel, and M. I. Semmel, Instructional Development for Training Teachers of Exceptional Children: A Sourcebook, no. Mc. Bloomington: Center for Innovation in Teaching the Handicappe, Indiana University, 1974.

[15] P. Barrouillet, "Theories of cognitive development : From Piaget to today," Dev. Rev., vol. 38, pp. 1-12, 2015.

[16] A. Arisetyawan, D. Suryadi, T. Herman, and C. Rahmat, "Study of Ethnomathematics : A lesson from the Baduy Culture," vol. 2, no. 10, pp. 681-688, 2014.

[17] B. Nurgiyantoro, "Tahapan Perkembangan Anak Dan Pemilihan Bacaan Sastra Anak," Cakrawala Pendidik., vol. 24, no. 2, pp. 197-216, 2005.

[18] R. A. Reiser and R. M. Gagne, "Characteristics of Media Selection Models," Rev. Educ. Res., vol. 52, no. 4, pp. 499-512, 1982.

[19] Pardimin and S. A. Widodo, "Development Comic Based Problem Solving in Geometry," Int. Electron. J. Math. Educ., vol. 12, no. 3, pp. 233-241, 2017.

[20] A. Muhson, "Pengembangan Media Pembelajaran Berbasis Teknologi Informasi," J. Pendidik. Akunt. Indones., vol. 8, no. 2, pp. 1-10, 2010.

[21] A. K. Ismail and P. Hendikawati, "EFEKTIVITAS MODEL PEMBELAJARAN TEAMS GROUP TOURNAMENT ( TGT ) DENGAN MENGGUNAKAN MEDIA ‘ 3 IN 1 , DALAM PEMBELAJARAN MATEMATIKA Info Artikel Abstra Pendahuluan," vol. 2, no. 2252, 2013.

[22] B. Susanto, Dwijanto, and Siskandar, "CELMI MEDIA PEMBELAJARAN BERBANTUAN TELEPHONE CELLULER UNTUK MENINGKATKAN KOMPETENSI PENYOLDERAN ELEKTRONIKA," Innov. J. Curric. Educ. Technol., vol. 1, no. 2, pp. 74-81, 2012. 
[23] I. S. Adi, I. G. Meter, M. G. R. Kristiantari, and M. Gagne, "PENGARUH MODEL PEMBELAJARAN RME BERBANTUAN MEDIA SEMI KONKRET TERHADAP HASIL BELAJAR MATEMATIKA SISWA KELAS VSD GUGUS 8 KECAMATAN GIANYAR , KABUPATEN Jurusan Pendidikan Guru Sekolah Dasar , FIP Universitas Pendidikan Ganesha," 2014.

[24] T. Nurseto, "Membuat Media Pembelajaran yang Menarik - Tejo Nurseto," Ekon. Pendidik., vol. 8, pp. 19-35, 2011.

[25] F. Nuzulah, M. Yadri, and L. Fitria, "AKSIOLOGI PENDIDIKAN MENURUT MACAM-MACAM FILSAFAT DUNIA (IDEALISME, REALISME, PRAGMATISME, EKSISTENSIALISME)," 1997. 